\title{
Drilling Waste Management and Control the Effects
}

\author{
Ahammad Sharif MD*, Nagalakshmi NVR, Srigowri Reddy S, Vasanth G and Uma Sankar K \\ Department of Petroleum Engineering, GIET College of Engineering, Rajahmundry, Andhra Pradesh, India
}

\begin{abstract}
Petroleum is among the world's most important natural resources. The production of petroleum involves the generation of drilling waste which forms a major source of pollution in oil producing environment. Almost every process in the finding and production of petroleum generates many types of wastes which impacts the environment negatively such as the generation and disposal of cuttings and excess drilling fluids. These materials are discharged overboard in offshore operations or buried when drilling in land-based locations. As an effort to manage and reduce the impact of drilling waste on the environment there have been a number of techniques. Technologies such as directional drilling, slim-hole drilling, coil-tubing drilling and pneumatic drilling are few of the drilling practices that generates less amount of drilling waste. In this we discuss the environmentally responsible actions that require an understanding of the types of wastes and how they are generated and also a number of drilling waste managing technologies of minimising and eliminating the effect of drilling waste on environment.
\end{abstract}

Keywords: Drilling waste management; Environment; Exploration and producing

\section{Introduction}

\section{Drilling waste}

All activities related to Oil \& Gas Exploration, Production, Storage and Transportation involve waste generation associated to potential risk to environment. Waste types are related to Exploration and Producing $(\mathrm{E} \& \mathrm{P})$ activities. These activities are: Drilling operations, Production operations, Completion operations, Work-over operations, Gas plant operations.

\section{Types of wastes}

During drilling operations, drilling fluid or mud is pumped down the drill string to lift drill cuttings to the surface. The drilling fluid together with the suspended drill cuttings and some heavy metals are carried through the annulus to the surface where the cuttings are separated from the fluid and the fluid is re-injected to lift more cuttings. The solid cuttings are then either treated and disposed of grinded into slurries and injected or kept in a waste pit for further treatment and disposal (Tables 1 and 2).

\section{Toxicity of drilling waste}

The toxicity of a substance is a measure of how it reduces the life and health of living organisms following exposure to the substance. In most cases, the effect of the substance on human life and health is of primary importance. Toxicities are determined through bioassays by exposing laboratory animals to different amounts of the substance in question (Res, 1993). The resulting effects on the health of the animals are observed. For oil and gas industries wastes, common test species used for marine waters are the mysid shrimp and sheepshead minnow, while fathead minnow and daphnid shrimp are used for fresh waters.

Two types of toxicity measurements are commonly used: dose and concentration. The dose is the concentration of a substance that has been absorbed into the sample tissue of the test species, while the concentration is measure of the concentration of a substance in the environment that the species lives in. Toxicity measurements using concentration also include a time interval of exposure. A dose that is lethal to $50 \%$ of the animals is called LD50, whiles the dose resulting in the first death is called LDLO. The dose levels required for any particular effect also depend on how the animals are exposed - by injection, ingestion, or inhalation. Similarly, a lethal concentration that kills $50 \%$ of the animals within a given period of time is called as LC50 whiles the lowest lethal concentration for the same period of time is called LCLO.

Concentration is the toxicity measure most commonly used for

\begin{tabular}{|c|c|c|}
\hline Type of Waste & Main components & $\begin{array}{l}\text { Possible environmentally } \\
\text { significant constituents }\end{array}$ \\
\hline Waste lubricants & Lube oil, grease & Heavy metals, organics \\
\hline Spacers & $\begin{array}{l}\text { Mineral oil, detergents, } \\
\text { surfactants }\end{array}$ & Hydrocarbon, alcohol, aromatic \\
\hline $\begin{array}{c}\text { Spent/ } \\
\text { contaminated } \\
\text { water based } \\
\text { muds (include } \\
\text { brine) }\end{array}$ & $\begin{array}{l}\text { Whole mud, mineral oil, } \\
\text { biodegradable matters }\end{array}$ & $\begin{array}{l}\text { Heavy metals, inorganic salts, } \\
\text { biocides, hydrocarbons, solids/ } \\
\text { cutting, BOD, organics }\end{array}$ \\
\hline $\begin{array}{l}\text { Water based } \\
\text { muds and cutting }\end{array}$ & $\begin{array}{l}\text { Formation solids, water } \\
\text { based muds mineral oil }\end{array}$ & $\begin{array}{l}\text { Heavy metals, inorganic salts, } \\
\text { biocides, hydrocarbons, } \\
\text { solid/cutting }\end{array}$ \\
\hline $\begin{array}{c}\text { Spent/ } \\
\text { contaminated oil } \\
\text { based muds }\end{array}$ & Whole mud mineral oil & $\begin{array}{l}\text { Hydrocarbons, heavy metals, } \\
\text { inorganic salts, solids, BOD, } \\
\text { organics, surfactants }\end{array}$ \\
\hline $\begin{array}{l}\text { Oil based muds } \\
\text { cuttings }\end{array}$ & $\begin{array}{l}\text { Formation solids, oil } \\
\text { based muds }\end{array}$ & $\begin{array}{l}\text { Heavy metals, inorganic salts, } \\
\text { hydrocarbons, solid/cutting }\end{array}$ \\
\hline $\begin{array}{l}\text { Spent bulk } \\
\text { chemical }\end{array}$ & $\begin{array}{l}\text { Cement, Bentonite, } \\
\text { barites, viscosities, } \\
\text { thinners, fluid loss } \\
\text { reducers, speciality } \\
\text { product }\end{array}$ & $\begin{array}{l}\text { Heavy metals, hydrocarbon, } \\
\text { organics, solids }\end{array}$ \\
\hline $\begin{array}{l}\text { Spent special } \\
\text { products }\end{array}$ & $\begin{array}{l}\text { H2S scavengers, } \\
\text { defoamers, tracers }\end{array}$ & $\begin{array}{l}\text { Zinc carbonates, iron oxides, } \\
\text { hydrocarbons, silicon oils, potassium } \\
\text { salts, radioactive material }\end{array}$ \\
\hline
\end{tabular}

*Corresponding author: Ahammad Sharif MD, Department of Petroleum Engineering, GIET College of Engineering, Rajahmundry, Andhra Pradesh, India, Tel: +919603056177; E-mail: ahmedsharif.chem95@gmail.com

Received March 23, 2017; Accepted April 05, 2017; Published April 07, 2017

Citation: Sharif MDA, Nagalakshmi NVR, Reddy SS, Vasanth G, Uma Sankar K (2017) Drilling Waste Management and Control the Effects. J Adv Chem Eng 7 : 166. doi: $10.4172 / 2090-4568.1000166$

Copyright: (๑) 2017 Sharif MDA, et al. This is an open-access article distributed under the terms of the Creative Commons Attribution License, which permits unrestricted use, distribution, and reproduction in any medium, provided the original author and source are credited. 
materials associated with the oil and gas industries. If a material is highly toxic, then only a small concentration will be lethal and the numerical values of the lethal doses and concentrations - LD50 and LDLO, would be low. Conversely, a high value of these parameters indicates low toxicity. LC50 values on the order of 10 are normally considered highly toxic.

\section{Impacts of drilling waste on the environment}

Many of the materials and wastes associated with drilling activities have the potential to impact on the environment negatively. The potential impact depends primarily on the material, its concentration after release of the biotic community that is exposed. Some environmental risks may be significant whiles others are very low. The major impacts of great concerns are pollution of water bodies, pollution of land, as well as air pollution. Improper disposal of contaminated drill cuttings into water bodies (ocean) exposes marine life to danger. Excessive release of air pollutants from internal combustion engines makes the air unsafe for both humans and animals and some of their effects includes respiratory difficulties in humans and animals, damage to vegetation and soil acidification. Release of hydrogen sulphide, of course, can be fatal to those exposed (Table 3).

\begin{tabular}{|c|c|c|c|c|c|c|}
\hline Element & Water & Cutting & Barite & Clay & Lignite & Caustic \\
\hline Aluminum & 0.3 & 40,400 & 40,400 & 88,600 & 6,700 & 0.013 \\
\hline Arsenic & 0.0005 & 3.9 & 34 & 3.9 & 10.1 & 0.039 \\
\hline Barium & 0.1 & 158 & 590,000 & 640 & 640 & 0.26 \\
\hline Calcium & 15 & 240,000 & 7,900 & 4,700 & 16,100 & 5,400 \\
\hline Cadium & 0.0001 & 0.08 & 6 & 0.5 & 0.2 & 0.0013 \\
\hline Chromium & 0.001 & 183 & 183 & 8.02 & 65.3 & 0.00066 \\
\hline Cobalt & 0.0002 & 2.9 & 3.8 & 2.9 & 5 & 0.00053 \\
\hline Copper & 0.003 & 22 & 49 & 8.18 & 22.9 & 0.039 \\
\hline Iron & 0.5 & 21,900 & 21,950 & 37,500 & 7,220 & 0.04 \\
\hline Lead & 0.003 & 37 & 685 & 27.1 & 5.4 & 0.004 \\
\hline Magnesium & 4 & 23,300 & 3,900 & 69,800 & 5,040 & 17,800 \\
\hline Mercury & 0.0001 & 0.12 & 4.1 & 0.12 & 0.2 & 4 \\
\hline Nickel & 0.0005 & 15 & 3 & 15 & 11.6 & 0.09 \\
\hline Potassium & 2.2 & 13,500 & 660 & 2,400 & 460 & 51,400 \\
\hline Silicon & 7 & 206,000 & 70,200 & 271,000 & 2,390 & 339 \\
\hline Sodium & 6 & 3,040 & 3,040 & 11,000 & 2,400 & 500,000 \\
\hline Strontium & 0.07 & 312 & 540 & 60.5 & 1030 & 105 \\
\hline Table & & & & & & \\
\hline
\end{tabular}

Table 2: Elemental Composition of Drilling Fluid Constituents $(\mathrm{Mg} / \mathrm{Kg})$.

\section{Environmental issues based on location}

The process of drilling oil and gas wells generates large volumes of drill cuttings and used muds. Onshore and offshore operators have employed a variety of methods for managing these drilling wastes. In offshore, options are limited to cuttings reinjection, offshore discharge and transportation to onshore disposal facility. This is as a result of the limited space and stringent environmental regulations governing an offshore drilling operation. As a result some offshore wastes have to be transported to an onshore facility for treatment and disposal. Onshore operations however, have a wider waste management options. The selection of a disposal method for a particular location depends on other factors which must be evaluated extensively before implementation. The main aim should be towards ensuring an environmentally safe waste disposal approaches (Figure 1).

In drilling operations, drilling mud is pumped down the drill string and ejected through the nozzles in the drill bit at high velocity and pressure to lift cuttings to the surface. At the surface, solids control equipment is used to remove the unwanted solids from the drilling fluid to provide the maximum practical recovery of drilling fluid for re-use. The recovered drilling fluid is re-circulated down the drill string to lift more cuttings and the cycle continues. The remaining solid component which forms the waste stream is then subjected to one of these disposal methods: Offshore Discharge, hauling to Onshore Facility or reinjection into the formation. Managing waste in an offshore operation is usually more challenging and costly than on onshore operation. This is due to the stringent environmental regulations governing offshore drilling operations as well as limited space available for operation (Figure 2).

\section{Solids control equipment}

The solids control system forms the first waste management practice in any drilling operation. It removes drill cuttings from the drilling mud at the surface just before the mud re-enters the mud-pit for recirculation. Apart from drill cuttings, the solids control equipment also removes some gases and other contaminants in the mud before they are re-circulated. The early removal of these solids avoids accumulation and clogging of the system and the separation devices sizes of solids (Table 4). The components of the solids control system will depend upon the types of drilling fluid used, these formations being drilled, the available equipment on the rig, and the specific requirements of the disposal option. But basically, standard solid control equipment will comprise of shale shakers, degassers, desanders and desilters. The mud passes over a shale shaker, which is basically a vibrating screen. This removes the larger particles, while allowing the residue to pass into settling tanks. The finer particles are further removed in the desanders and desilters. If the mud contains gas from the formation it will be passed through a degasser which separates the gas from liquid mud,

\begin{tabular}{|c|c|c|c|c|}
\hline Activity & Source & Potential Impact & $\begin{array}{l}\text { Component } \\
\text { Affected }\end{array}$ & Effects \\
\hline $\begin{array}{l}\text { Onshore (Exploratory and } \\
\text { Appraisal Drilling) }\end{array}$ & Operations & $\begin{array}{c}\text { Discharges, Emissions, } \\
\text { Waste }\end{array}$ & $\mathrm{H} / \mathrm{At} / \mathrm{B} / \mathrm{Aq} / \mathrm{T}$ & $\begin{array}{l}\text { Water supply requirements, noise, vibration and emissions from plant equipment } \\
\text { and transport, extraneous light, liquid discharges: muds and cuttings, wash water, } \\
\text { drainage, soil contamination: mud pits, spillage, leakages: Solid Waste Disposal: } \\
\text { Sanitary Waste Disposal, sewage, camp grey water: emissions and discharges } \\
\text { from well test operations: additional noise and light from burning/flare, Disturbance } \\
\text { to wildlife }\end{array}$ \\
\hline $\begin{array}{l}\text { Offshore (Exploratory and } \\
\text { Appraisal Drilling) }\end{array}$ & Operations & $\begin{array}{c}\text { Discharges, Emissions, } \\
\text { Wastes }\end{array}$ & $\mathrm{H} / \mathrm{At} / \mathrm{B} / \mathrm{Aq} / \mathrm{T}$ & $\begin{array}{l}\text { Discharge to ocean: mud, cuttings, wash water, drainage, sewage, sanitary and } \\
\text { kitchen wastes, spillage and leakages, Emissions from plant equipment: noise and } \\
\text { light: solid waste disposal onshore and impact on local infrastructure. Disturbance } \\
\text { to benthic and pelagic organisms, marine birds. Changes in sediment, water and air } \\
\text { quality. Loss of access and disturbance to other marine resource users. Emissions } \\
\text { and discharges from well test operations produced water discharges, burning and } \\
\text { flare. Effect of vessel and helicopter movement on human and wildlife }\end{array}$ \\
\hline
\end{tabular}

Table 3: Potential Environmental Impacts of Drilling Operations. 


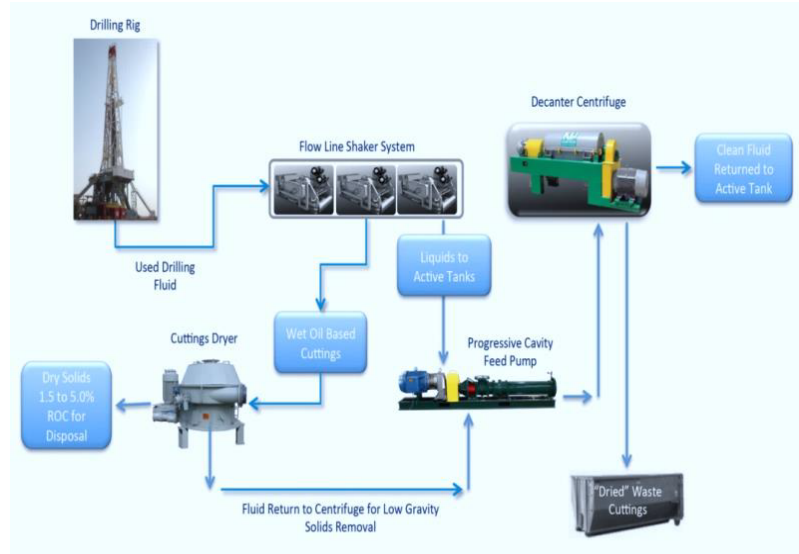

Figure 1: The process of drilling oil and gas wells generates large volumes of drill cuttings and used muds.

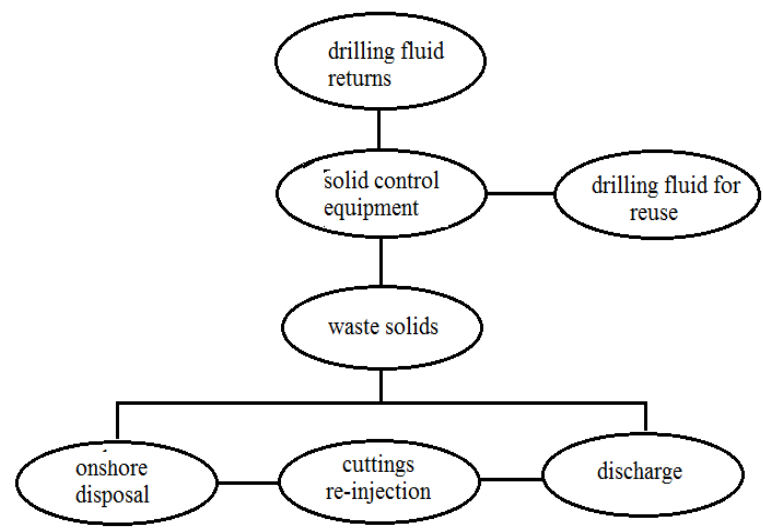

Figure 2: Offshore Waste Management.

\begin{tabular}{|c|c|c|}
\hline Classification of solids & Examples & Particle size ranges \\
\hline coarse & Small cuttings, gravel & $>2000$ microns \\
\hline Intermediate & Coarse sand & $250-2000$ microns \\
\hline Medium & Fine sand & $74-250$ microns \\
\hline Fine & Coarse silt & $44-74$ microns \\
\hline Ultra-fine & Barite, fine silt & $2-44$ microns \\
\hline Colloidal & Bentonite, clay & $<2$ microns \\
\hline
\end{tabular}

Table 4: Classification and Size of Solids.

having passed through all the mud processing equipment the mud is returned to the mud tanks for recycling, while the residue (drill cuttings with adhered drilling fluid) is either kept in a temporary storage facility for treatment and final disposal or direct discharged into the sea. In general, the solids control equipment reduces the volume of drilling waste requiring disposal (Figure 3 ).

\section{Materials and Methods}

\section{Disposal methods for offshore operations}

There are three basic drilling waste disposal options for offshore operations. These are offshore discharge, cuttings reinjection, and hauling to an onshore facility. The choice of disposal method to adopt is usually a very challenging task as this depends on other factors like the ecological conditions, environmental regulation and cost. For instance, it is cheaper to discharge waste into the ocean than to haul the waste to an onshore waste disposal facility, however, the environmental requirements for waste discharge is very stringent: waste must be treated to an acceptable level before being discharged and this implies extra cost. It is therefore highly recommended that, before any waste disposal method is selected, an extensive economic and environmental analysis be performed to evaluate the options. If offshore discharge is the selected disposal method, there will be no need for storage facilities.

Offshore discharge: Discharging drilling waste into the ocean is perhaps the most economical and operationally safe disposal method. This is because; it does not require additional equipment than that conventionally found on the rig OGP. This method of disposal is suitable for aqueous-based cuttings as they require little or no treatment before disposal. Non-aqueous based fluids, must however be treated to an environmentally accepted level before being discharged into the sea. Factors to consider when selecting this option include the sensitivity and capacity of the potential receiving environment, the concentration of potential dangerous components in the waste and the volume of the discharge stream.

The residue (cuttings with adhering drilling fluids) is mixed with sea water and discharged to the sea through a pipe known as "downcomer". The end of the downcomer is typically located a few meters below the water surface OGP. The discharged residue will fall to the seafloor and accumulate to different degrees. For non-aqueous drilling fluids, concentration in the sediments will typically be elevated and benthic biota may be affected. With time the concentration will reduce and biota will recover but the time scales vary depending upon the thickness of the accumulation, and the characteristics of the receiving. Recoveries for thicker accumulations are thought to be much slower than for thin accumulations. Impacts to water column are considered negligible, because the cuttings settle quickly and the water solubility of the base fluids is low. A large cuttings pile and its residual drilling fluid load, poses a problem for facility decommissioning. Leaving the pile in-situ may provide a source of environmental contamination by uptake and bioaccumulation during the natural recovery of the site. Disturbance of a pile during the decommissioning and removal of the platform may significantly increase the potential for adverse impacts in the wider marine environment (Table 5).

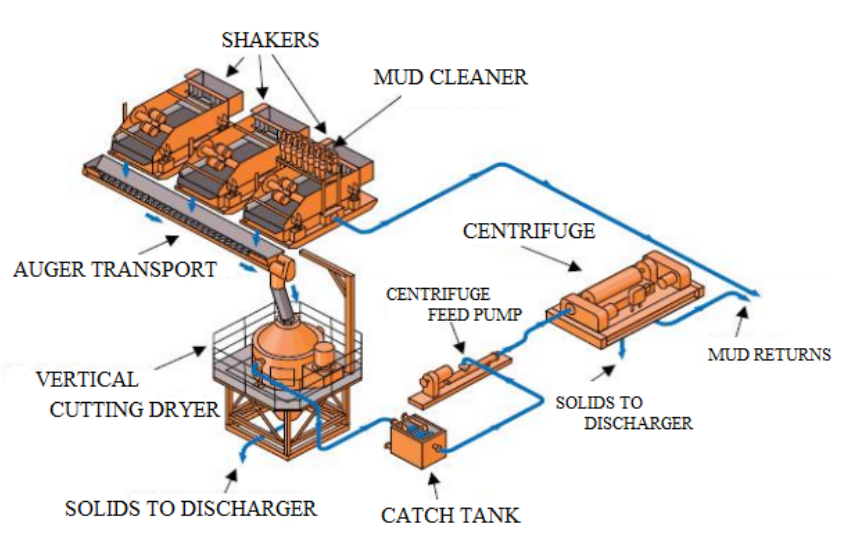

Figure 3: Standard solid control equipment. 


\begin{tabular}{|c|c|c|}
\hline Section & Advantages & Disadvantages \\
\hline Economics & $\begin{array}{l}\text { - Very low cost per unit volume treatment } \\
\text { - No potential liabilities at the onshore facilities }\end{array}$ & $\begin{array}{c}- \text { Potential future liabilities } \\
\text { - Cost of analysis of discharges and potential impacts (e.g. compliance testing, } \\
\text { discharge modelling, field monitoring program) }\end{array}$ \\
\hline Operational & $\begin{array}{c}\text { - Simple process with little equipment needed } \\
\bullet \text { No transportation cost involved } \\
\bullet \text { Low power requirements } \\
\bullet \text { Low personnel requirements } \\
\text { - Low safety risk } \\
\text { - No shore-based infrastructure required } \\
\text { - No additional space or storage required } \\
\text { - No weather restrictions }\end{array}$ & - Management requirements of fluid constituents \\
\hline Environmental & $\begin{array}{l}\text { - No incremental air emissions } \\
\bullet \text { Low energy usage } \\
\text { - No environmental issues at onshore sites }\end{array}$ & - Potential for short-term localized impacts on seafloor biology \\
\hline
\end{tabular}

Table 5: Advantages and Disadvantages of Offshore Discharge.

Cuttings reinjection: Recent strict regulations do not allow dumping of contaminated waste directly into the sea. As a result, reinjection of exploratory and drilling wastes, especially the drill cuttings is becoming more common practice when possible. Slurry injection technology involves the grinding of solids into small particles, mixing them with water or some other liquid to make slurry and injecting the slurry into an underground at pressures high enough to fracture the rock. The two common ways by which slurries are injected into the formations are through the annulus of the well or into a dedicated disposal well. Disposal wells are designed to provide a means of transporting fluid waste into an underground geologic formation in a manner that will not adversely affect the environment (Figure 4).

The choice of the optimum injection method must be made with reference to both operational and economic considerations. Drilling a dedicated injection well is sometimes ruled out in favour of an annular injection plan on a cost basis but more frequently, operators are deciding not to risk damaging their well and would rather drill a separate shallow injection well. The candidate formation for disposal must be geologically and mechanically isolated from usable sources of water to avoid seepage of the waste into the water body. This formation must not hold oil or gas in commercial quantities. Again the formation must have a good porosity and permeability. The process is recognized as highly environmentally friendly and has proven to be more economical than the disposal of drill cuttings onshore (Table 6).

Transporting to onshore: This involves the hauling of cuttings and associated drilling fluid to an onshore treatment facility if necessary and finally disposed of by techniques such as land farming/land-spreading, injection or reuse. These techniques are applicable to non-aqueous drilling waste which cannot be discharged or re-injected due to its toxic nature or volume. Factors to consider when evaluating these methods include the availability and cost of chattering a vessel and distance from platform to shore. It is important to evaluate the cost of chattering or transporting waste to shore before considering this option (Table 7).

\section{Disposal methods for onshore operations}

Cutting reinjection is common to both offshore and onshore operations. However, due to the availability of space for an onshore operation, there are a lot more management options available. The most common onshore disposal method is perhaps onsite burial. Other methods include the construction of a waste reserve pit, thermal methods like incineration, kilns, open burning etc. There are also biological methods like composting, land-spreading, land-farming etc. In an onshore environment, waste can be treated and used for other beneficial applications like road spreading, construction materials etc. This section explores the various options available for onshore waste treatment and disposal

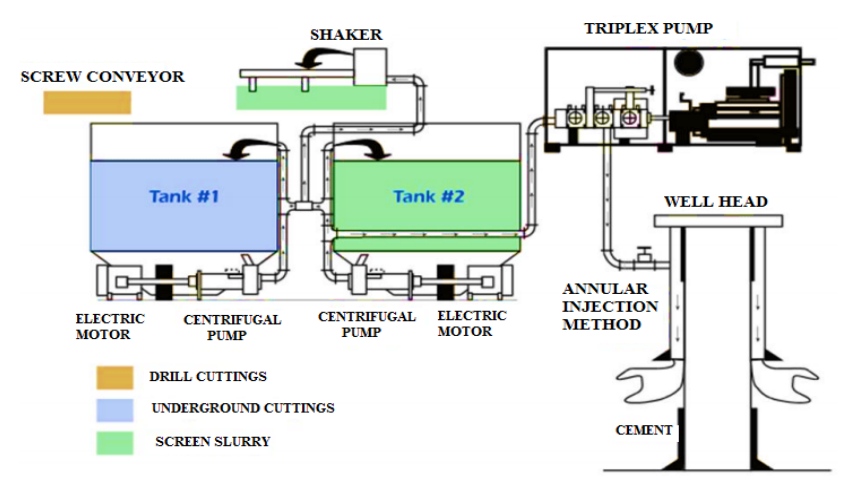

Offshore Cuttings Re-injection

Figure 4: Offshore Cuttings Re-injection.

Onsite burial: Burial is the placement of waste in a man-made or natural excavation such as pits or landfills. Due to its simplicity, it has remained the most common onshore disposal technique for disposing drilling wastes. Other advantages of this method include low cost, low technology and also do not require transportation of waste from the well site. With the current awareness of pollutant migration pathways, the risks associated with burial of wastes should be carefully considered. For waste that contains high concentrations of oil, salt, biologically available metals, industrial chemicals and other materials with harmful components that can contaminate usable water resources, onsite burial may not be a good option. Burial is a logical choice for wastes that have been stabilized, since migration of the constituents of the waste will be retarded by the stabilization process.

The disadvantage of this method is that, burial usually results in anaerobic conditions. This limits any further degradation when compared with wastes that are land-farmed or land-spread, where aerobic conditions predominate. For proper protection of soils and water resources, consideration of factors such as the depth to groundwater, and the type of soil surrounding the pit should be made before wastes are buried. Finally, when burial and/or pit closure is complete, the area should be graded to prevent water accumulation, and re-vegetated with native species to reduce potential for erosion and promote full recovery of the area's ecosystem.

Waste pits: The use of waste pits (earthen or lined) is an essential part of any onshore drilling waste management operation. While serving many purposes, one of the primary purposes is to collect and hold all 
Citation: Sharif MDA, Nagalakshmi NVR, Reddy SS, Vasanth G, Uma Sankar K (2017) Drilling Waste Management and Control the Effects. J Adv Chem Eng 7: 166. doi: 10.4172/2090-4568.1000166

Page 5 of 9

\begin{tabular}{|c|c|c|}
\hline Section & Advantages & Disadvantages \\
\hline Economics & $\begin{array}{l}- \text { Enables use of a less expensive drilling fluid } \\
\bullet \text { No offshore transportation needed } \\
\text { - Ability to dispose of other wastes that would have to be taken to shore for disposal }\end{array}$ & $\begin{array}{l}\text { - Expensive and labour intensive } \\
\text { - Shutdown of equipment can halt drilling activities }\end{array}$ \\
\hline Operational & $\begin{array}{l}\text { - Cuttings can be injected if pre-treated } \\
\text { P Proven technology }\end{array}$ & $\begin{array}{c}\text { - Extensive equipment and labour-requirement } \\
\text { - Application requires receiving formation with appropriate } \\
\text { properties } \\
\text { - Difficult for exploratory wells due to lack of knowledge } \\
\text { of the formation }\end{array}$ \\
\hline Environmental & $\begin{array}{l}\bullet \text { Elimination of seafloor impact } \\
\text { - Limits possibility of surface and ground water contamination }\end{array}$ & $\begin{array}{l}\text { - Increase in air pollution due to large power } \\
\text { requirements }\end{array}$ \\
\hline
\end{tabular}

Table 6: The advantages and Disadvantages Cuttings Reinjection Disposal Method.

\begin{tabular}{|c|c|c|}
\hline Section & Advantages & Disadvantages \\
\hline Economics & $\begin{array}{l}\text { - Waste can be removed from drilling location eliminating } \\
\text { future liability at the rig site } \\
\text { - Transportation cost can be high for vessel rental and vary } \\
\text { with distance of shore base from the drilling location }\end{array}$ & $\begin{array}{c}\text { - Transportation may require chartering of additional supply vessel } \\
\text { - Additional costs associated with offshore transport equipment (vacuum augers, } \\
\text { cuttings boxes or bulk containers) and personnel }\end{array}$ \\
\hline Operational & & $\begin{array}{l}\text { - Safety hazards associated with loading and unloading of waste containers on and at } \\
\text { the shore-base } \\
\text { - Increased handling of waste is necessary at the drilling location and at shore-base } \\
\text { Additional personnel required } \\
\text { - Risk of exposure of personnel to aromatic hydrocarbons is greater } \\
\text { - Efficient collection and transportation of waste are necessary at the drilling location }\end{array}$ \\
\hline Environmental & $\begin{array}{l}\text { - No impacts on benthic community } \\
\text { - Avoids impacts to environmentally sensitive areas offshore } \\
\text { - Fuel use and consequent air emissions associated with } \\
\text { transfer of wastes to shore-base }\end{array}$ & $\begin{array}{l}\text { - Increased risk of spills in transfer (transport to shore and offloading) } \\
\text { - Disposal onshore creates new problems (e.g., Ground water contamination) }\end{array}$ \\
\hline
\end{tabular}

Table 7: The advantages and Disadvantages of Onshore Disposal Method.

of the drilling associated wastes generated from the drilling operation. Other uses include evaporation and storage of produced water and management of work-over/completion fluids and for emergency containment of produced fluids. Waste pits must be strategically located to prevent spillage of waste materials onto the drilling or production site or into nearby water body or residential area. To prevent seepage into ground water bodies and contamination of the soil, the pits are usually lined with natural and or synthetic liners (Figure 5).

Although pits are an accepted component of any drilling waste management program, they may represent an environmental liability if managed improperly. Reserve pits can contaminate soil, groundwater, and surface-water with metals fluids and hydrocarbons if not managed and closed proper. As reserve pit fluids evaporate, water-soluble metals, salts, and other chemicals become concentrated. Precipitation, changes in shallow groundwater levels and flooding can transfer these contaminants into adjacent soils and groundwater; Liners most often do not adequately seal the drilling wastes, especially if they are torn. Following well completion, reserve pits are left in place after the drilling rig and other equipment are removed from the site. Reserve pit fluids are try to dry and the remaining solids are encapsulated with the reserve pit synthetic liner and buried in place.

Landfills: Under this option, cuttings, either treated or untreated, are placed in a containment unit with a liner and cover that have been designed to contain the waste. The ability of the landfill to contain waste will depend upon the quality of the design and materials, and underlying geological units. A key consideration in the operation of a landfill site is the need to ensure long-term containment because landfilled wastes are not destroyed, but are actually in long-term storage. Landfills are usually operated by offsite commercial operators in which case waste can be received from different drilling sites. However, some oil companies with large amount of drilling activities may construct and operate private landfills (Figure 6).

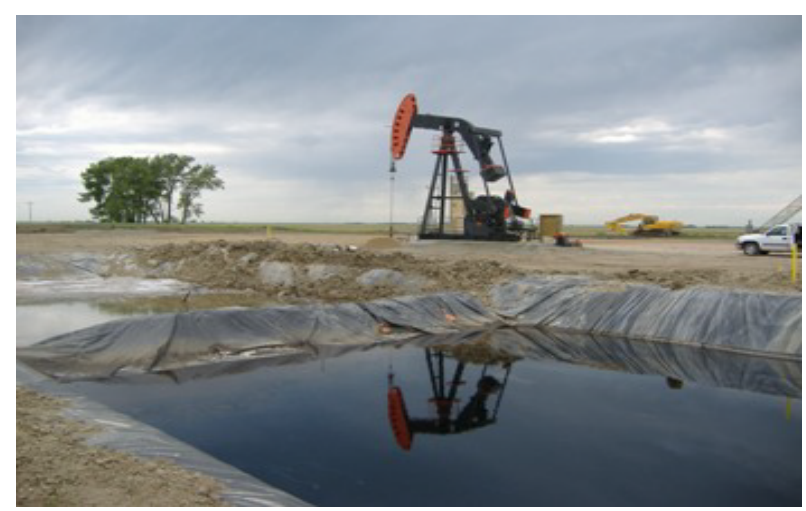

Figure 5: Drilling waste management program.

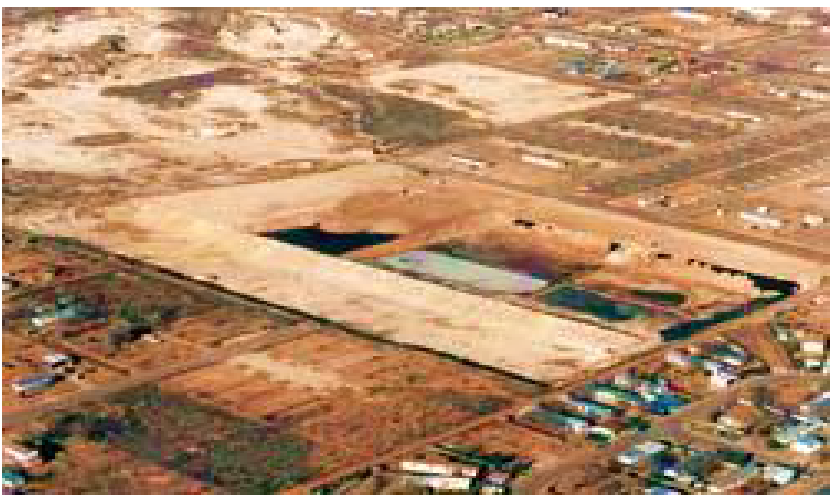

Figure 6: Commercial Oilfield Waste Landfill (Aird, 2008). 
Bioremediation: This is a treatment process that uses naturally occurring micro-organisms to break down and degrade organic substances. The micro-organisms break down the organic substances into harmless carbon dioxide and water. Once the wastes are degraded, the micro-organism population will reduce naturally as they will have nothing to feed on. Bioremediation process is fairly flexible and can be used for all manner of drill cuttings and other wastes. Some advantages of bioremediation are: it is relatively environmental benign; it generates few emissions; wastes are converted into useful products and it requires minimal, if any, transportation. There are various forms of bioremediation but the common types are land-farming/landspreading, composting, and vermin-culture.

Land-farming /land spreading: This waste management technique can be considered both as a treatment method and a disposal methods. The aim behind this method is to allow the soils naturally occurring microbial organisms to metabolize, transform and assimilate waste constituents in place. In general, land farming refers to the repeated application of untreated waste to the soil surface whereas land spreading refers to the one time application of the waste to the soil surface. This is usually followed by mechanical tilling with addition of nutrients, water, air and or oxygen to stimulate biodegradation and aeration of the soil by naturally occurring oil-degrading bacteria. This method of drilling waste management is relatively low cost and may even improve the water retaining capacity of sandy soils. Depending upon the location of the land-farm, a liner, over liner, and/or sprinkler system may be required. Both land-spreading and land-farming are more efficient in warm tropical climates, and may be inapplicable in areas where the ground is frozen in most part of the year.

Composting: Composting involves the mixing of drilling waste with bulking agents such as wood chips, straw, rice hulls or husks to provide increased porosity and aeration potential for biological degradation. Manure and other agricultural wastes are usually added to increase the water holding capacity of the waste/media mixture and to provide trace nutrients. Adding nitrogen and phosphorus-based fertilizers and trace metals also enhance microbial activity and reduce the time required to achieve the desired level of biodegradation.

Mixtures of the waste, soil and other additives, may be placed in piles small enough like less than 3 feet deep to be tilled for aeration, or placed in containers or on platforms designed to allow forcing of air through the composting mixture. The combination of placing the material in a pile, and addition of bulking agent result in high temperatures in the pile, which further increase rates of biodegradation and volatilization gives composting an advantage over land-spreading or land-farming in cold climates. Composited wastes that meet healthbased criteria can be used to condition soil, cover landfills and supply clean fills (Figure 7).

Vermi-culture: This method of treating waste was developed by a research group in New Zealand. It involves using earthworms to enhance the bioremediation process and convert the drill cuttings into organic fertilizer. The process has been tested and proven successful in treating certain synthetic-based wastes. The contaminated drill cuttings are mixed with sawdust, undigested grass, and water and applied to worm lines. The feeding consists of applying the mixture as feedstock to windrows which are covered to exclude light from the worm bed and protect it from becoming waterlogged. This technique of treating waste not only cleanses the cuttings but also converts them into a valuable resource (Figure 8).

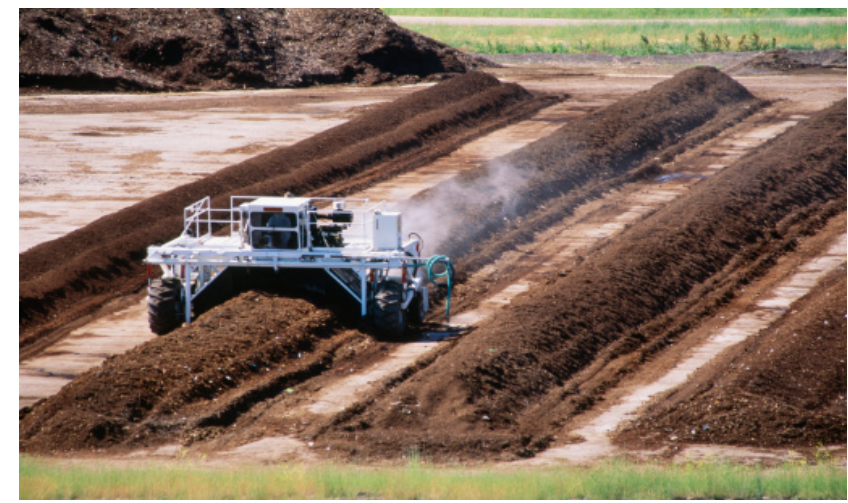

Figure 7: Compost in Windrows.

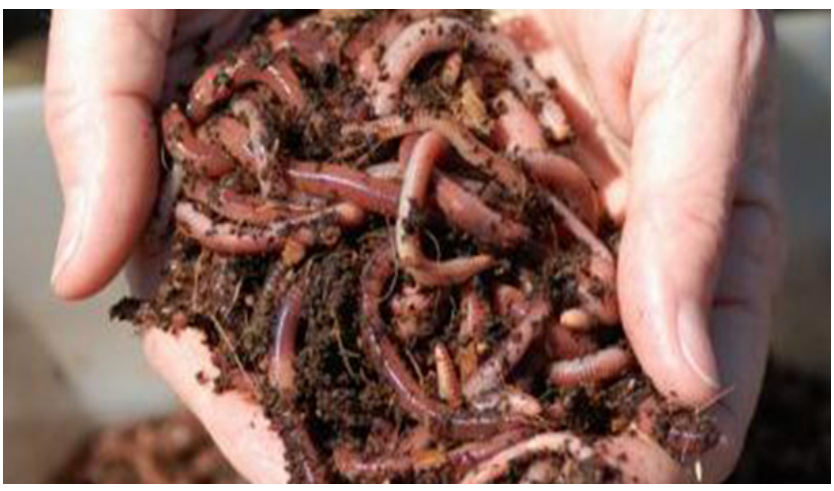

Figure 8: Vermi-culture Showing Worms.

\section{Thermal methods}

Thermal technologies that have been used to treat wastes include thermal desorption and incineration. With thermal desorption, the cuttings are placed in a treatment unit and then heated. The liquids are volatilized and re-condensed back to two phases: water and oil. The resulting waste streams are water, oil and solids. The wastewater will require treatment prior to disposal. The resulting solid residue has essentially no residual hydrocarbons, but does retain salt and heavy metals, and can be disposed of in a landfill or by land-spreading, or may be used in road construction. Incineration involves heating cuttings in direct contact with combustion gases and oxidizing the hydrocarbons. Solid/ash and vapour phases are generated. Incineration can be performed by open burning of wastes in pits or by the use of commercial incinerators. In order to ensure the removal of incomplete combustion products, incinerators emitting particulates, SOx and NOx are often equipped with air pollution control devices. Stabilization of residual materials may be required prior to disposal to prevent constituents from leaching into the environment.

Other beneficial uses of drilling wastes: Treated or untreated drilling waste can be converted to other useful materials. However, before cuttings can be used for other beneficial purposes, it is necessary to ensure that the hydrocarbon fluid content, moisture content, salinity and clay content are suitable for the intended use of the material. Among the many beneficial uses of drilling wastes, two are very pronounced; road spreading and construction of building materials. Other proposed applications include incorporation into roofing tiles, use for trench 
cover, soil reconditioning, restoration of wetlands and use of cuttings as fuels. Most of these applications are however just proposals and have not yet been implemented or demonstrated on the field.

Road spreading: Drilling wastes are mixed with other construction materials and spread over gravel roads. The oily waste acts as an effective binding material which helps hold the road materials together and making such wastes an effective dust suppressant. Research has shown that the environmental impact of road spreading is low for properly prepared wastes. The metal contents of most oily wastes can be lower than that of asphalt; a common road paving material. Most of the wastes used for road spreading are of high volume, low toxicity solids; hence, disposal by road spreading reduces that volume of waste has must be disposed of in overused landfills. Nevertheless, the lack of control over the spread of wastes is expected to limit and may even prohibit its future use.

Re-use of cuttings as construction materials: After treating drilling wastes to remove all the liquid contents, the clean solid residue can be employed in the manufacturing of construction materials. Some of the possible applications include the use of drill cuttings as a fill material, aggregate or filler in concrete, brick or block manufacturing. The economics of this technique must not be based on the value of the finished product but on the cost of other disposal methods. Usually, the cost of treating waste to remove all possible liquid contaminants makes this method less preferable to other methods like land-farming and composting.

\section{Minimization and management of drilling waste}

Waste management refers to ways by which the generation and pollution of waste could be controlled to minimize or eliminate its negative impact on the environment. Over the past decade, there has been an increasing international concern for proper waste management in order to minimize their potential to cause harm to human health and the environment. The overall aim of managing drilling waste is to cut down on cost. As a result, effective and responsible waste management has been a key element of any organization's environmental management system. Besides, effective waste management practices will not only be a valuable tool for waste minimization programs, but also, source of data in the event of any question of liability for contamination, and site remediation. Waste management includes the incorporation of a hierarchy of waste management practices in the development of waste management plans. Being able to identify and quantify waste stream and assessing its potential impacts on the environment can help provide a baseline for identification of opportunities to improve practices. The potential benefits to a company that implements an effective waste management practices include:

- Increased revenue;

- $\quad$ Reduced costs of operating, materials, waste management and disposal, energy, and facility clean-up;

- Improved operating efficiency;

- Reduced regulatory compliance concerns;

- $\quad$ Reduced potential for both civil and criminal liability; and

- $\quad$ Enhanced public perception of the company and the industry as a whole.

Waste management hierarchy: Generally, the waste hierarchy refers to the "3 Rs" Reduce, Reuse and Recycle, which classify waste management strategies according to their desirability in terms of waste minimization. It is usually represented by an inverted triangle with reduction occupying the upper portion, followed by reuse and finally recycling. In some instances waste treatment and disposal is incorporated as the least preferred option in the hierarchy. Proper management of wastes begins with pollution prevention. Pollution prevention refers to the elimination, change or reduction of operating practices which result in discharges to land, air or water. If elimination of a waste is not possible, then minimizing the amount of waste generated should be investigated.

Source reduction: Source reduction involves the process of controlling waste generation at source. This might include generating less discharges through more efficient practices, or looking into the possibilities for horizontal drilling, slim hole drilling, downsized casing designs etc. Source reduction is given the highest priority in the waste management hierarchy for the reason that avoiding waste generation together, or generating the least toxic waste possible, minimizes the problems associated with waste management. Waste that is not generated need not be managed and waste the generated, but is of the lowest possible volume and/or toxicity can be managed most costeffectively. The generation of less waste involves practices such as: material elimination, inventory control and management, material substitution, process modification etc.

Waste recycling: In instances where source reduction is not technically and economically feasible, recycling methods must be considered. Recycling involves the conversion of wastes into usable materials and/or extraction of energy or materials from wastes. Recycling may also involve the use or reuse of a waste as a substitute for a commercial product, or as feedstock in an industrial process. Recycle helps to preserve of raw materials and reduces the amount of material that requires disposals.

Waste reuse or recovery: The use of materials or products that is reusable in their original form such as oily wastes for road construction and stabilization and burning waste oil for energy lessens the quantity of the waste released into the environment. If feasible, drilling fluid may be reused in another drilling project. The result of this is a significant cost savings and highly reduced waste management concerns. If reuse within a company is not feasible, there are several companies that take waste drilling fluids for reconditioning and reuse. This also has an economic benefit in that; materials that are to be disposed at a cost may be reused for extra income.

Waste disposal: From an environmental perspectives are disposal at the least preferred waste management option. Disposal generally involves the discharge, deposition, injection, dumping, spilling, leaking, or placing of any waste into or on land, water, or air. Disposal also involves the greatest potential liability and as such is the least preferred waste management option (Figure 9).

Practices that minimize drilling waste generation: Waste minimization program is an important element of any control the waste management plan. As shown in the waste hierarchy, waste minimization or source reduction is the most preferred waste management practice. Where possible, the volume of waste released into the environment must be reduced. By reducing the volume, the potential toxicity and effects to the environment is minimized. It is also more economical to manage less volume of waste. Source reduction or minimization of waste also has operational advantages as less waste implies less personnel and equipment on board. The various waste disposal options for both offshore and onshore operations have been discussed in chapter three. This section identifies practical drilling practices that minimize the volume of waste generated. 
Directional drilling: Directional drilling allows drilling to be made at angles off the vertical. It involves the use of steerable/directional down hole tools allowing the driller to direct the wellbore in any angle to reach the target. Directional drilling allows drilling to be made in environmentally sensitive areas. Thus, a drilling rig could be sighted about several miles away and yet drill a target located underneath a market centre. This reduces the environmental impacts of drilling especially air pollution on the public. Usually, directional drilling is more expensive and more difficult than conventional vertical techniques; however, it improves the efficiency and economy of oil recovery operations. Above all, directional drilling also generates a smaller volume of cuttings compared to the conventional vertical drilling technique. This is because; a reservoir which could be depleted with three conventional vertical wells with its associated wastes could be depleted with a single horizontal well with lesser volume of cuttings. Three variations of directional drilling include extended-reach drilling, horizontal drilling and multiple laterals of a single main well bore are a picture of the various kinds of directional drilling (Figure 10).

Techniques that uses less drilling fluid: From all indications, oil based mud performs better than water-based muds. This is in line with its ability to perform well in difficult drilling situations like deep wells, highly deviated wells and reactive shale's. However, the environmental concerns associated with oil-based muds are very enormous and hence the environmental regulations governing its use are usually very rigid. In order to maintain the desirable properties of oil-based mud with a

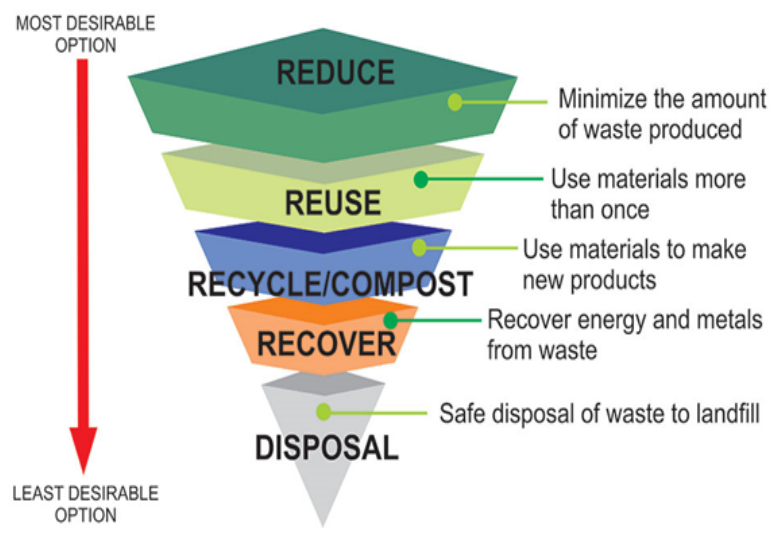

WASTE MANAGEMENT HIERARCHY

Figure 9: Waste Management Hierarchy.

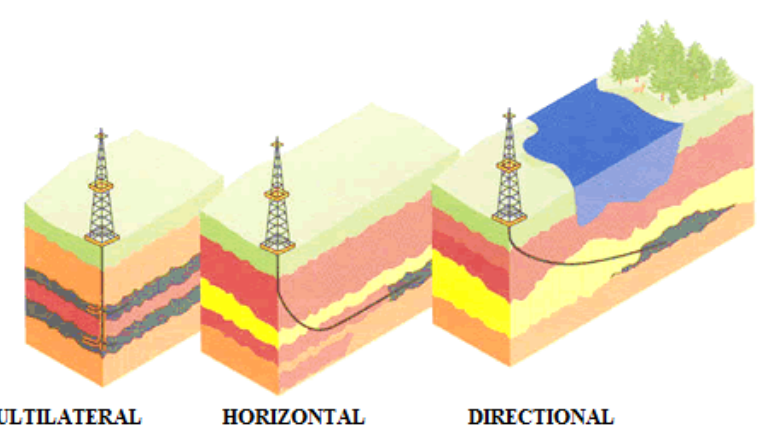

Figure 10: Directional Drilling Technology. lower environmental impact, the synthetic-based mud was developed. Synthetic-based muds share the desirable drilling properties of oil-based muds but are free of poly-nuclear aromatic hydrocarbons, have lower toxicity, faster biodegradability and lower bioaccumulation potential. It drills a cleaner hole than water-based muds with less sloughing, and generates a lower volume of drill cuttings. Where practicable, synthetic based muds must be used instead of oil based muds due to their environmentally friendly nature.

The use of pneumatic drilling is another way of reducing the environmental effects of drilling fluids. Pneumatic drilling is the use of air or other forms of gases to circulate cuttings out from the well. There are four basic types of pneumatic drilling: air dust drilling, air mist drilling, foam drilling and aerated mud drilling. Pneumatic drilling does not require the large surface reserve pits common to traditional drilling thereby making it possible to be used in environmentally sensitive areas. Elsewhere palm oil has been used to design a more environmentally benign drilling fluid. Air drilling may be favours over drilling using water-base or oil-base fluids when the underlying formation are hard and dry or in shallow locations where are the use of fluids to maintain subsurface pressures are not required. In these circumstances, air drilling is considerably faster and less expensive than drilling using water-base or oil-base fluids.

Use of a cleaner energy source: The most frequently used source of energy for running drilling activities on the rig is the internal combustion engines. These engines are usually powered either by natural gas or diesel fuel. Their operation introduces oxides of nitrogen and partially burned hydrocarbons which are harmful to both human health and the environment. The use of other alternative clean energy sources such as solar, hydro and wind to power the drilling rig will eliminate or reduce some of these harmful effects to the environment [1-12].

\section{Results and Discussion}

\section{Waste volume estimation}

The volume of waste generated when drilling a well is an important and costly element of any comprehensive waste management plan. It serves as an appropriate planning tool as most of the components of waste management plan depend on it. The amount of waste can be calculated in advance so that waste disposal can be planned. For instance, suitable waste minimization plans could only be drawn if the volume of waste to be generated is approximately known. Again, requirements for containers and support vessels will depend upon the volume of cuttings. For offshore operations, once the wastes are brought ashore, treatment and disposal costs will be dependent upon this volume as well. However, not enough research has been conducted on waste volume estimation. Proper waste management must account for the quantity of waste generated. The total volume of cutting waste generated per well can be estimated as the sum of the nominal volume of hole drilled, the amount of hole washout, and the volume of drilling fluid retained on the cuttings summarizes some applications of waste volume estimation (Figures 11).

\section{Governing equations for waste volume estimation}

Several researchers have developed different equations for estimating waste volume. The dry drill cuttings volume is estimated based on equations. In this estimation, the dry drill cuttings are equivalent to gauge hole volume plus washout.

Drill hole volume $\left[\mathrm{ft}^{3}\right]=\left(\frac{\mathrm{WF}}{\mathrm{SF}}\right) \times(1+$ washout factor of 0.075$)$ 


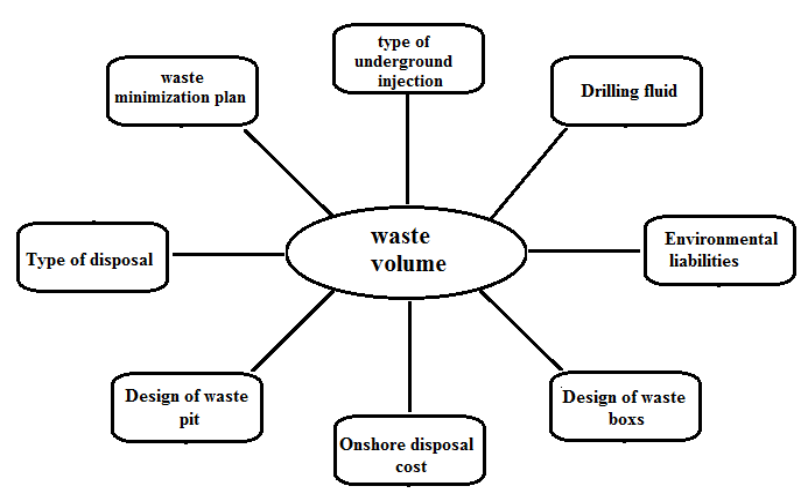

Figure 11: Applications of Waste Volume Estimation.

Where: $\mathrm{D}=$ Hole Diameter, $\mathrm{ft}$

$$
\mathrm{L}=\text { Hole Length, } \mathrm{ft}
$$

Drill cuttings [bbls] $=$ hole volume $\times 0.1781 \mathrm{bbls} / \mathrm{ft}^{3}$

Drill cuttings $[\mathrm{lbs}]=$ drill cuttings $[\mathrm{bbls}] \times 910 \mathrm{lbs} / \mathrm{bbls}$

Waste Components are estimated following Equations. The units are in lbs.

Total waste $[\mathrm{TW}]=$ base fluid+water+barite+drill cuttings

$\mathrm{TW}=(\mathrm{RF} \times \mathrm{TW})+\left(\left[\mathrm{RF} \times\left(\frac{\mathrm{WF}}{\mathrm{SF}}\right)\right] \times \mathrm{TW}\right)+\left(\left[\mathrm{RF} \times\left(\frac{\mathrm{BF}}{\mathrm{SF}}\right)\right] \times\right.$
$\mathrm{W})+(\mathrm{DF} \times \mathrm{TW})$

Where: TW=total waste [whole drilling fluid+dry cuttings], lbs

$\mathrm{RF}=$ report weight fraction of synthetic base fluid

$\mathrm{WF}=$ water weight fraction from drilling fluid formation

$\mathrm{SF}=$ synthetic base fluid weight fraction from drilling fluid formation

$\mathrm{BF}=$ barite weight fraction from drilling fluid formation

$\mathrm{DF}=$ drill cutting weight fraction

DF is calculated as follows:

$\mathrm{DF}=1-\left(\mathrm{RF} \times\left[1+\left(\frac{\mathrm{BF}}{\mathrm{SF}}\right)+\left(\frac{\mathrm{BF}}{\mathrm{SF}}\right)\right]\right)$

Total waste volume is calculated as; the whole drilling fluid volume is estimated equation

TW $=\frac{\text { drilling cuttings, lbs }}{\mathrm{DF}}$

The whole drilling fluid volume is estimated equation

Whole SBF volume [bbls]=synthetic base fluid [bbls]+water [bbls]+barite [bbls].

The formation oil in whole mud discharged is $0.2 \%$ [volume] calculated based equation.

Formation oil [bbls] $=0.002 \times$ whole SBF volume [bbls].

\section{Conclusion}

Based on the theoretical and practical observations made from this work, the following deductions and conclusions can be made:

- Waste volume estimations plays a critical role in managing drilling and associated waste and should at all-times be estimated and incorporated into the waste management plan.

- The disposal and waste management cost is directly related to the volume of waste generated and as such, minimization as a waste management method must be a priority to other methods.

- Selection of the optimum drilling waste management method must always be subjected to extensive environmental, technical and economic analysis as these are the main drivers. A screening criteria has been developed to help quicken the decision making process.

- For effective drilling waste management, the ten waste management steps must be critical.

\section{References}

1. Anon A (2011) Drilling Engineering Lecture Notes. Heriot-Watt University, Department of Petroleum Engineering, Edinburgh, Scotland.

2. Aird P (2008) Drilling Waste Management Technology Descriptions, USDOE, 2011.

3. Anon A (2011) The importance of oil, 2011

4. Anon A (2011) Waste Management, 2011.

5. Anon A (2011) Drilling Fluids, 2011.

6. Carole F, Catalin I, William AP (2010) Theoretical and Practical Models for Drilling Waste Volume Calculation with Field Case Studies.

7. Gbokoyi A (2011) Horizontal Well Technology - Lecture Notes. African University of Science and Technology, AUST, Abuja, Nigeria.

8. International Petroleum Industry Environmental Conservation Association (IPIECA) (2009) Drilling fluids and health risk management - A guide for drilling personnel, managers andhealth professionals in the oil and gas industry. OGP Report Number 396, Prepared on behalf of the OGP/IPIECA Health Committee by the Drilling Fluids Task Force.

9. Osisanya S (2011) Waste Management Plan. Lecture Notes, African University of Science and Technology, AUST, Abuja, Nigeria.

10. Ramirez P Jr (2009) Reserve Pit Management: Risks to Migratory Birds. US Fish and Wildlife Service Region 6, Environmental Contaminant Program, Cheyenne, Wyoming, USA.

11. Rena S (2008) Facts and Data on Environmental Risks - Oil and Gas Drilling Operations, SPE 114993, Presented at the 2008 SPE Asia Pacific Oil and Gas Conference and Exhibition held in Perth, Australia.

12. ANL (2011) Drilling Waste Management Information System. Argonne National Laboratory, US Department of Energy. 